March 2005

\title{
Does Exchange Rate Risk Affect Exports Asymmetrically? Asian Evidence
}

WenShwo Fang

Feng Chia University

YiHao Lai

Feng Chia University

Stephen M. Miller

University of Connecticut and University of Nevada, Las Vegas

Follow this and additional works at: https://opencommons.uconn.edu/econ_wpapers

\section{Recommended Citation}

Fang, WenShwo; Lai, YiHao; and Miller, Stephen M., "Does Exchange Rate Risk Affect Exports Asymmetrically? Asian Evidence" (2005). Economics Working Papers. 200509.

https://opencommons.uconn.edu/econ_wpapers/200509 


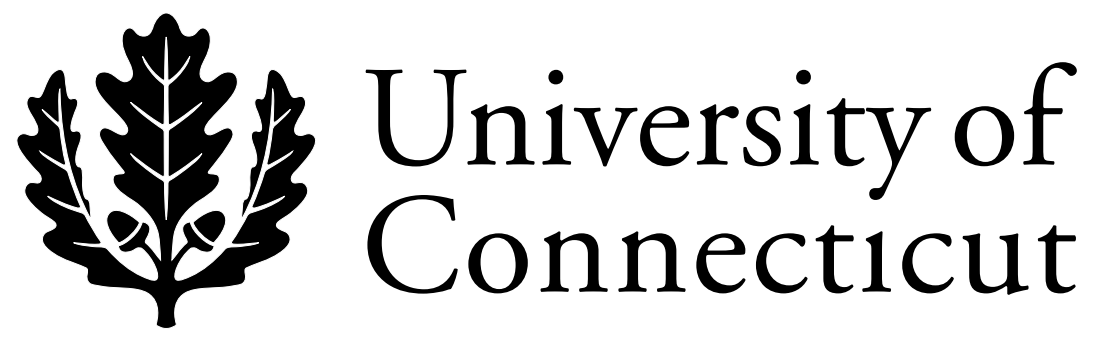

Department of Economics Working Paper Series

Does Exchange Rate Risk Affect Exports Asymmetrically? Asian Evidence

WenShwo Fang

Feng Chia University

YiHao Lai

Feng Chia University

Stephen M. Miller

University of Connecticut and University of Nevada Las Vegas

Working Paper 2005-09

March 2005

341 Mansfield Road, Unit 1063

Storrs, CT 06269-1063

Phone: (860) 486-3022

Fax: (860) 486-4463

http://www.econ.uconn.edu/ 


\begin{abstract}
The effects of exchange rate risk have interested researchers, since the collapse of fixed exchange rates. Little consensus exists, however, regarding its effect on exports. Previous studies implicitly assume symmetry. This paper tests the hypothesis of asymmetric effects of exchange rate risk with a dynamic conditional correlation bivariate $\mathrm{GARCH}(1,1)-\mathrm{M}$ model. The asymmetry means that exchange rate risk (volatility) affects exports differently during appreciations and depreciations of the exchange rate. The data include bilateral exports from eight Asian countries to the US. The empirical results show that real exchange rate risk significantly affects exports for all countries, negative or positive, in periods of depreciation or appreciation. For five of the eight countries, the effects of exchange risk are asymmetric. Thus, policy makers can consider the stability of the exchange rate in addition to its depreciation as a method of stimulating export growth.
\end{abstract}

Journal of Economic Literature Classification: C32, F14, F31, F41

Keywords: depreciation, exchange rate risk, exports, bivariate GARCH-M model 


\section{Does Exchange Rate Risk Affect Exports Asymmetrically? Asian Evidence}

\section{Introduction}

The relationship between exchange rate risk and exports has received considerable attention since the collapse of fixed exchange rates in the early 1970s. Ethier (1973) argues that exchange rate risk could lower exports due to profit risk. De Grauwe (1988), however, suggests that exporters might increase exports to offset potential revenue losses. Broll and Eckwert (1999) note that the price of an option to export increases with risk. Pozo (1992) uncovers a negative effect of exchange rate risk on UK exports to the US. Chowdhury (1993) and Arize (1995, 1996, 1997) find negative effects of exchange rate risk on US, European, and G7 exports. Weliwita, Ekanayake, and Tsujii (1999) and Fang and Thompson (2004) provide evidence of negative effects for Sri Lanka and Taiwan. Arize, Osang, and Slottje (2000) and Arize, Malindretos, and Kasibhatla (2003) conclude that exchange rate risk generates a negative effect on LDC exports, using a moving sample standard deviation model. In contrast, Asseery and Peel (1991) find positive effects for multilateral exports except for the UK. Kroner and Lastrapes (1993) discover positive effects for France, Germany, and Japan, but negative effects for the UK and the US. McKenzie and Brooks (1997) report positive effects for Germany and the US. Finally, Klaassen (2004) reports no effect of monthly bilateral US exports on other G7 countries.

While a variety of theoretical and empirical models attempt to isolate quantitatively important effects of exchange rate risk on exports, all work proceeds under the assumption of symmetry, meaning that no difference exists between the risk effects of exchange rate appreciation and depreciation. Tse and Tsui (1997) find that a depreciation shock produces a greater effect on future volatility in exchange rates than an appreciation shock of the same magnitude. Risk-averse exporters behave differently when facing different degrees of foreign exchange market volatility. Thus, different risk effects emerge under conditions of exchange rate 
depreciation and appreciation. This paper tests the hypothesis of asymmetric effects of exchange rate risk on exports, where the asymmetry measures possible differences in the exchange rate risk (volatility) effect when the exchange rate appreciates and depreciates.

No empirical studies directly test whether exchange rate risk acts symmetrically or asymmetrically. Some inferences emerge from the research on export price adjustments to exchange rate changes (Krugman 1987, Sercu 1992, Knetter 1994, Kanas 1997, and Mahdavi 2000). These papers establish the hypothesis that the risk profile of economic exposure exhibits asymmetry. That is, changes in the export price differ between real depreciations and real appreciations. Our paper considers whether we observe different exchange rate risk effects on exports between depreciations and appreciations.

Whether asymmetric risk effects exist proves important to policy makers. Conventional wisdom argues that depreciation increases exports, but exchange rate risk induced by the depreciation can hurt exports. Thus, market intervention to stimulate exports may fail, if the authorities ignore the effects of exchange rate risk. Fang and Thompson (2004) show that exports respond positively to depreciations and negatively to risk effects, but the net effect only adds noise to export fundamentals. The existence of asymmetric risk effects further complicates and increases the uncertainty of trade policy. Thus, successful trade policy requires a full understanding and control of exchange risk during periods of depreciation and appreciation.

To study the effects of exchange rate risk requires a measure of the unobservable exchange rate risk. Hodrick and Srivastava (1984) identify exchange risk as conditional and time varying. Moving standard deviations of the exchange rate maintain the hypothesis of homoskedascity while serving as a proxy for heteroskedastic risk in Chowdhury (1993), Arize, Osang, and Slottje (2000), and Arize, Malindretos, and Kasibhatla (2003). This approach raises a logical inconsistency and probably proves inadequate to capture fully exchange rate risk 
dynamics. Generalized autoregressive conditional heteroskedasticity (GARCH) models can successfully model relationships between means and variances as in Bollerslev $(1986,1990)$, Engle et al. (1987), and Bollerslev et al. (1992). This paper specifies exchange rate risk as time-varying exchange rate volatility constructed with a $\mathrm{GARCH}(1,1)$ process following Bollerslev (1986), such that a larger estimated conditional variance indicates more risk.

This paper contributes to the literature by using the bivariate GARCH-M model with dynamic conditional correlation (DCC) (Engle 2002) in measuring the exchange rate risk effect on exports and testing for asymmetry. Engle's DCC approach allows time-varying correlations between exports and the exchange rate. It differs from previous studies that implicitly assume a constant correlation. This paper uses monthly time-series data on bilateral exports from eight Asian countries -- Indonesia, Japan, Korea, Malaysia, Philippines, Singapore, Taiwan, and Thailand -- to the US for 1979 to 2003. The majority of existing studies consider developed countries, but the eight Asian countries, except Japan, industrialized during this period. Klaassen (2004) suggests that developing countries provide a better laboratory to study the effect of exchange risk on exports. Table 1 reports that the US accounts for a substantial portion of exports from these Asian countries. The average US share of total exports over the sample ranges from 16 percent for Indonesia to 34 percent for the Philippines. The bilateral approach can avoid asymmetric responses across exchange rates in highly aggregated data, and then focus on the asymmetric effects of the exchange rate risk.

After testing the time-series properties of the variables and identifying the GARCH or ARCH effects of the exchange rates, the empirical results of our bivariate GARCH-M DCC model provides some support for the asymmetry hypothesis. In each country, positive depreciation effects exist along with negative or positive exchange risk effects during depreciations or appreciations. For five of the eight countries, significant asymmetric effects of 
the exchange risk on exports occur. The evidence supports the uncertainty of exchange rate policies designed to influence exports.

The rest of this paper is organized as follows. Section 2 specifies the analytical framework, which includes the main elements of the time-varying correlation bivariate GARCH-M model designed to test for the asymmetric hypothesis of the exchange risk. Section 3 describes that data, analyzes the time-varying variances of exports and the exchange rates, and presents empirical results. Section 4 investigates the asymmetric effects of exchange rate risk on exports. Section 5 summarizes the empirical findings and provides concluding remarks.

\section{The Bivariate GARCH-M Model and Testing for Asymmetric Effects}

The nonstructural reduced-form export equation of Rose (1990), Pozo (1992), and Klaassen (2004) provides the building block for our empirical analysis of the asymmetric effects of exchange rate risk on Asian exports to the United States. Real export revenue $(x)$ depends on real foreign income $(y)$, the real exchange rate $(q)$, and real exchange rate risk $\left(h_{q}\right)$. Real export revenue equals nominal export revenue in domestic currency deflated by the consumer price index (CPI). Foreign income, the US industrial production index, should produce a positive effect on exports. The real exchange rate, the domestic currency price of the US dollar times the ratio of US to domestic CPIs, should exhibit a positive effect on exports. The real exchange rate eliminates potential ambiguity from adjusting price levels. The effect of exchange rate risk proves uncertain theoretically and empirically.

To capture dynamic adjustments, the following eclectic bivariate GARCH-M-DCC model provides the framework for investigating and testing the asymmetric hypothesis.

$$
\begin{gathered}
\Delta l x_{t}=a_{0}+\sum_{i=1}^{2} a_{i} \Delta l x_{t-i}+\sum_{i=0}^{2} b_{i} \Delta l y_{t-i}+\sum_{i=0}^{2} c_{i} \Delta l q_{t-i}+\sum_{i=0}^{2} d_{i} h_{q, t-i}^{1 / 2}+\varepsilon_{x, t} \\
\Delta l q_{t}=s_{0}+s_{1} \varepsilon_{t-1}+\sum_{i=1}^{2} \gamma_{i} M D_{i}+\varepsilon_{q, t}
\end{gathered}
$$




$$
\begin{gathered}
\varepsilon_{t} \mid \Psi_{t-1} \sim \text { Student }-t(v) \\
h_{x, t}=\alpha_{0}+\alpha_{1} \varepsilon_{x, t-1}^{2}+\alpha_{2} h_{x, t-1} \\
h_{q, t}=\beta_{0}+\beta_{1} \varepsilon_{q, t-1}^{2}+\beta_{2} h_{q, t-1}+\sum_{i}^{2} \lambda_{i} V D_{i} \\
D_{t}^{2}=\left[\begin{array}{cc}
h_{q, t} & 0 \\
0 & h_{x, t}
\end{array}\right] \\
\eta_{t}=D_{t}^{-1} \varepsilon_{t} \\
Q_{t}=\bar{\rho}_{x q}\left(1-\theta_{1}-\theta_{2}\right)+\theta_{1} \eta_{t-1} \eta_{t-1}^{\prime}+\theta_{2} Q_{t-1} \\
R_{t}=\operatorname{diag}\left\{Q_{t}\right\}^{-1} Q_{t} \operatorname{diag}\left\{Q_{t}\right\}^{-1}
\end{gathered}
$$

where $\Delta l x_{t} \equiv 100 \times\left(\ln x_{t}-\ln x_{t-1}\right), \Delta l y_{t} \equiv 100 \times\left(\ln y_{t}-\ln y_{t-1}\right)$, and $\Delta l q_{t} \equiv 100 \times\left(\ln q_{t}-\ln q_{t-1}\right)$. The lag structure of the mean equation of $\Delta l x_{t}$ is selected by the Schwartz Information Criteria (SIC) and $\varepsilon_{x, t}$ is a white noise. $h_{q, t}$ is time varying exchange rate volatility estimated by the $\operatorname{GARCH}(1,1)$ process. The presence of the square root of $h_{q, t}, h_{q, t}^{1 / 2}$, in the mean equation of $\Delta l x_{t}$ constitutes the bivariate GARCH-M model. The MA component picks up serial dependence of $\Delta l q_{t}$ to ensure that $\varepsilon_{q, t}$ is white noise. The residual matrix, $\varepsilon_{t}$, conditional on the information set $\Psi_{t-1}$ available at time $t-1$ follows a bivariate Student-t distribution with degrees of freedom $v$. Our sample includes the Asian financial crisis in 1997, which exhibited dramatic movements in exchange rates in most Asian countries. $M D_{i}$ and $V D_{i}$ are dummy variables employed to capture extraordinary exchange rate changes in the mean and the variance equations for $\Delta l q_{t} \cdot h_{x, t}$ measures the conditional variance of exports. Conditions, $\alpha_{i}>0$, $\beta_{i}>0, \lambda_{i}>0, \alpha_{1}+\alpha_{2}<1$ and $\beta_{1}+\beta_{2}<1$, imply positive and stable conditional variances of $\varepsilon_{x, t}$ and $\varepsilon_{q, t}$. If $\alpha_{2}$ or $\beta_{2}$ equal zero, the process reduces to an $\operatorname{ARCH}(1)$. The matrix $D_{t}^{2}$ 
contains $h_{x, t}$ and $h_{q, t}$ along the principle diagonal and thus, $\eta_{t}$ is the standardized residual matrix. $Q_{t}$ is the covariance matrix of $\eta_{t}$, following a $\operatorname{GARCH}(1,1)$ process. $\bar{\rho}_{x q}$ is the unconditional correlation of exports and the exchange rates over the sample period. $\theta_{1}$ and $\theta_{2}$ positive and $\theta_{1}+\theta_{2}<1$ ensure that $Q_{t}$ is positively defined and mean-reverting. $R_{t}$ is the conditional correlation matrix composed of time-varying correlations. Equations (1) to (9) constitute the DCC estimator proposed by Engle (2002). If $\theta_{1}=\theta_{2}=0$, then it reduces to the Bollerslev (1990) constant conditional coefficient estimator.

Let $\Phi$ denote the parameters in $D_{t}^{2}$ that includes all parameters in equations (1) to (5) and $\Theta$ denote the parameters in $R_{t}$ that includes $\theta_{1}$ and $\theta_{2}$. Then, the $\log$ likelihood function of bivariate t-distribution in the maximization procedure is

$$
L(\Phi, \Theta)=\sum_{t=1}^{T} L_{t}(\Phi, \Theta)
$$

where $\quad L_{t}(\Phi, \Theta)=\ln \Gamma\left(\frac{v+2}{2}\right)-\ln \Gamma\left(\frac{v}{2}\right)-\ln [\pi(v-2)]-\frac{1}{2} \ln \left|D_{t} R_{t} D_{t}\right|-\frac{v+2}{2} \ln \left(1+\frac{\eta_{t}^{\prime} D_{t}^{-1} R_{t}^{-1} D_{t}^{-1} \eta_{t}}{v-2}\right) \quad$ and $\quad \Gamma(\bullet)$ represents the Gamma function.

The model focuses on the effects of exchange rate movements on exports and the reduced-form export equation includes depreciation and exchange rate risk as well as the rate of change of foreign income as explanatory variables. The signs, magnitudes, and significance of the estimated coefficients $\left(c_{i}\right)$ in equation (1) provide a straightforward test of the relationship between exports and depreciation, where $\sum c_{i}>0$ implies that depreciation improves exports. Also of interest are the signs, magnitudes, and significance of the estimated coefficients of exchange rate risk $\left(h_{q, t}^{1 / 2}\right)$ in equation (1). If exporters reduce their exports to minimize profit 
uncertainty during periods of exchange rate fluctuations, then $\sum d_{i}<0$. If, however, exporters intend to offset potential losses or use options markets as a hedge, then $\sum d_{i}>0$. As the equation constrains the $d_{i} \mathrm{~s}$ to remain constant for the exchange risk variable during both appreciations and depreciations, equation (1) implicitly assumes a symmetric response of the export revenue to the exchange rate risk.

To test for asymmetric effects, we test the hypothesis that $d_{i}$ differs between appreciations and depreciations. Let $d_{i}=d_{1 i}+d_{2 i} D$, where the dummy $D=1$ for $\Delta l q_{t}<0$ (i.e. an appreciation) and 0 for $\Delta l q_{t} \geq 0$ (i.e. a depreciation). Equation (1) becomes

$$
\Delta l x_{t}=a_{0}+\sum_{i=1}^{2} a_{i} \Delta l x_{t-i}+\sum_{i=0}^{2} b_{i} \Delta l y_{t-i}+\sum_{i=0}^{2} c_{i} \Delta l q_{t-i}+\sum_{i=0}^{2} d_{1 i} h_{q, t-i}^{1 / 2}+\sum_{i=0}^{2} d_{2 i}\left(D h_{q, t-i}^{1 / 2}\right)+\varepsilon_{x, t}
$$

The estimated relations are as follows:

$$
\begin{aligned}
& \text { Depreciation: } \Delta l x_{t}=\hat{a}_{0}+\sum_{i=1}^{2} \hat{a}_{i} \Delta l x_{t-i}+\sum_{i=0}^{2} \hat{b}_{i} \Delta l y_{t-i}+\sum_{i=0}^{2} \hat{c}_{i} \Delta l q_{t-i}+\sum_{i=0}^{2} \hat{d}_{1 i} h_{q, t-i}^{1 / 2}+\varepsilon_{x, t} \text { and } \\
& \text { Appreciation: } \Delta l x_{t}=\hat{a}_{0}+\sum_{i=1}^{2} \hat{a}_{i} \Delta l x_{t-i}+\sum_{i=0}^{2} \hat{b}_{i} \Delta l y_{t-i}+\sum_{i=0}^{2} \hat{c}_{i} \Delta l q_{t-i}+\sum_{i=0}^{2}\left(\hat{d}_{1 i}+\hat{d}_{2 i}\right) h_{q, t-i}^{1 / 2}+\varepsilon_{x, t},
\end{aligned}
$$

where $\sum \hat{d}_{2 i}$ measures the difference in the effects of the exchange rate risk between appreciations and depreciations. Equation (1a) replaces equation (1) in estimating our bivariate GARCH-M model. Statistical evidence consistent with an asymmetric effect exists, if either $\sum \hat{d}_{1 i}$, or $\sum\left(\hat{d}_{1 i}+\hat{d}_{2 i}\right)$, (or both) significantly differs from zero and the two sums differ significantly from each other (or $\sum \hat{d}_{2 i}$ differs significantly from zero). If both sums prove statistically insignificant, then the exchange rate risk causes no effect on exports.

\section{Data and Empirical Results}

For each of the eight countries, the bilateral export variable equals monthly seasonally adjusted real export revenue for the US from January 1979 to April 2003 with a base year of 1995. All data come from the International Financial Statistics and Direction of Trade of the IMF, except 
for Taiwan, where the data come from AREMOS. Table 2 reports preliminary statistics for the natural logarithmic differences of exports and the real exchange rate. Every country experienced depreciation and export growth over the sample, on average. Thailand exhibits the highest average export growth at 1.031 percent with a depreciation of 0.196 percent. Indonesia exhibits the highest monthly depreciation at 0.336 percent and an export growth of 0.486 percent. Thus, depreciation positively associates with exports, on average.

The unconditional risk measured by standard deviations shows that Indonesia exhibits the most volatile exchange rate and exports while Japan and Singapore exhibit the least volatile exports and exchange rates, respectively. Export volatility exceeds exchange rate volatility in every country. A general pattern of volatility's effect on exports does not emerge from standard deviations and the extreme values.

Skewness statistics reject $\Delta l x_{t}$ symmetry at the 5-percent level for Taiwan and $\Delta l q_{t}$ symmetry for every country, except Singapore and Taiwan. Kurtosis statistics for $\Delta x_{t}$ and $\Delta l q_{t}$ imply that all series are leptokurtic with fat tails. Jarque-Bera tests reject normality for all variables and countries, suggesting the use of the Student-t distribution in model estimation. The Ljung-Box Q-statistic tests for autocorrelation, where the number of lags $(k)$ affects its power. Tsay (2002) suggests choosing $k=\ln (T)$ where $T$ equals the number of observations (291), implying $k=5.67$. Thus, the autocorrelations tests run up to 6 lags. Ljung-Box Q-statistics indicate autocorrelation in $\Delta l x_{t}$ and $\Delta l q_{t}$ for all countries. Ljung-Box Q-statistics for squared $\Delta l x_{t}$ and $\Delta l q_{t}$ suggest time-varying variances for both series in all countries, except for $\Delta l q_{t}$ in the Philippines and Taiwan. An ARMA process for mean and variance equations captures the dynamic structure to generate white-noise residuals. In the model, we employ an $\operatorname{AR}(2)$ process for the mean equation of $\Delta l x_{t}$; an MA(1) process for the mean equation of $\Delta l q_{t}$; and $\operatorname{GARCH}(1,1)$ processes for equations (4) and (5), the two variance equations. 
Valid inference in GARCH models requires stationary variables. After selecting lag lengths by the Schwartz Information Criterion (SIC), the augmented Dickey-Fuller (ADF) test shows that $\Delta l x_{t}$ and $\Delta l q_{t}$ are individually stationary [I(0)] series at the 5-percent level.

The correlation coefficient between the two monthly log differenced series ranges from 0.018 in Taiwan to 0.259 in the Philippines. Figure 1 shows the sample correlation coefficient using a moving window of 12 observations (i.e., 1 year). The horizontal line denotes the correlation coefficient. The correlations change over time and, except for Japan, appear to increase in recent years for most countries, especially Indonesia and Korea. Engle (2002), Tsay (2002), and Tse and Tsui (2002) provide evidence that the estimation of a time-varying correlation GARCH model improves over that of a constant correlation model. This paper applies Engle's (2002) dynamic conditional correlation bivariate GARCH modeling approach. The bivariate GARCH model consists of two sets of equations. The first set of equations consists of a bivariate GARCH $(1,1)$ model for the conditional variances in equations (1a) to (5) and the second set, a GARCH $(1,1)$ model for the correlation coefficient in equations (6) to (9).

Preliminary examination shows that the standard univariate $\operatorname{GARCH}(1,1)$ model for $\Delta l q_{t}$ performs adequately for Japan, Singapore, and Taiwan. ${ }^{1}$ Unstable variance processes emerge, however, in Indonesia, Korea, Malaysia, the Philippines, and Thailand because the Asian financial crisis increased exchange market volatility immediately. Neglecting structural breaks may bias upward GARCH estimates of the persistence in variance, vitiating the use of GARCH to estimate the mean equation. Perron $(1989,1997)$ suggests identifying break points by examining data and using dummy variables to capture shifts in mean or variance processes. Figure 2 shows time plots of the eight exchange rates, marking the break dates.

\footnotetext{
${ }^{1}$ This result appears reasonable, since Japan, Singapore, and Taiwan were not significantly affected by the Asian financial crisis (see Figure 2).
} 
One-time shocks appear as single pulses in the depreciation series and as mean shifts in volatility. Dummy variables enter the mean equation for Indonesia and Thailand and the variance equations for Indonesia, Korea, Malaysia, the Philippines, and Thailand. In the mean equations, dummies for Indonesia are $\mathrm{MD}_{1}=1$ for $\mathrm{t}=1983: 04, \mathrm{MD}_{2}=1$ for $\mathrm{t}=1986: 09$, and 0 otherwise; for Thailand, $\mathrm{MD}_{1}=1$ for $\mathrm{t}=1981: 07, \mathrm{MD}_{2}=1$ for $\mathrm{t}=1984: 11$, and 0 otherwise. In the variance equations, dummies for Indonesia are $\mathrm{VD}_{1}=1$ for $\mathrm{t} \geq 1997: 07$, and 0 otherwise; for Korea $\mathrm{VD}_{1}$ $=1$ for $\mathrm{t} \geq 1997: 07$, and 0 otherwise; for Malaysia $\mathrm{VD}_{1}=1$ for 1997:07 $\leq \mathrm{t} \leq 1998: 12$, and 0 otherwise; for the Philippines $\mathrm{VD}_{1}=1$ for 1983:01 $\leq \mathrm{t} \leq 1984: 12, \mathrm{VD}_{2}=1$ for 1997:07 $\leq \mathrm{t} \leq$ 1998:12, and 0 otherwise; for Thailand $\mathrm{VD}_{1}=1$ for $\mathrm{t} \geq 1997: 07$, and 0 otherwise. The 1997 Asian crisis raised exchange rate volatility in Indonesia, Korea, Malaysia, the Philippines, and Thailand. The Philippines also experienced another volatile period from 1983 through 1984.

The properties of the time varying variance and correlation in exports and exchange rates suggest the bivariate GARCH(1,1)-M model with dynamic conditional correlation specified in equations (1a) to (9) to investigate the asymmetric effect of exchange rate risk. The general model is estimated first. Although neither autocorrelation nor heteroskedasticity exist, insignificant coefficients make it difficult to gauge the effect of the risk. Table 3 reports estimated coefficients and standard errors for a parsimonious version with insignificant variables deleted. The advantages of the parsimonious specification include higher precision of estimates from reduced multicollinearity, increased degrees of freedom, more reliable estimates, and greater power of tests. The insignificant likelihood ratio statistic, $\operatorname{LR}(\mathrm{k})$, at the 5-percent level suggests no difference between the general and the parsimonious models for each country.

All estimates of the ARMA components and dummy variables in mean equations (1a) and (2) are significant and the parameters in the two variance equations are positive. Every country exhibits time-varying variances for exports and exchange rates, suggesting the bivariate GARCH 
model. The significance of $\lambda_{1}$ and $\lambda_{2}$ in equation (5) confirms the use of dummy variables to alleviate the effect of structural breaks. Volatility persistence for $\Delta l x_{t}$ varies from 0.177 in Taiwan to 0.981 in Indonesia, and for $\Delta l q_{t}$ from 0.186 in Taiwan to 0.885 in Thailand. The two variance processes converge. Joint estimates of the degrees of freedom of the t-distribution are significant, the hypothesis of the multivariate Student-t distribution is not rejected.

Both $\theta_{1}$ and $\theta_{2}$ in the $\operatorname{GARCH}(1,1)$ process of $Q_{t}$ are significantly positive and $\theta_{1}+\theta_{2}<1$. The sum of $\theta_{1}+\theta_{2}$ lie between 0.662 in the Philippines and 0.962 in Malaysia. Table 4 reports statistics of conditional correlation coefficients between $\Delta l x_{t}$ and $\Delta l q_{t}$, using the bivariate GARCH(1,1)-M-DCC model of equations (1a) to (9). The average of the coefficients ranges from 0.011 in Malaysia to 0.201 in Japan. The mean or the median is close to the unconditional coefficient in Table 2. Values of the maximum, the minimum, and the standard deviation show that the coefficient is not constant. Figure 3 plots the fitted conditional correlation coefficient between $\Delta l x_{t}$ and $\Delta l q_{t}$. The plot illustrates that the correlation coefficient fluctuates over time, similar to that of Figure 1. This characteristic along with the non-zero estimates for $\theta_{1}$ and $\theta_{2}$ suggests the use of the time-varying correlation coefficient model for each country.

Bivariate Ljung-Box $Q_{2}(k)$ statistics (Hosking, 1980) for standardized residuals and squared standardized residuals of $\Delta l x_{t}$ and $\Delta l q_{t}$ do not detect remaining autocorrelation or conditional heteroskedasticity at the 5-percent level. The bivariate GARCH-M DCC model in equations (1a) to (9) adequately represent each country.

The marginal effect of US manufacturing income on exports proves significantly positive 
for all countries. Seven of the eight Asian countries experience contemporaneous effects, three experience one-month-lagged, and two experience two-month-lagged effects. The cumulative effect ranges from 1.745 for Malaysia, 2.371 for Japan, to 3.282 for Thailand. Different countries respond differently to the US economy. Generally, quick adjustments and large estimates reflect the small open-economy property of these economies.

Depreciation exhibits the expected positive effect on exports for the eight countries studied, but these effects prove insignificant only in Malaysia and Singapore. ${ }^{2}$ The cumulative depreciation effect ranges from 0.226 for Singapore to 2.477 for Korea. Every country exhibits lower individual or cumulative depreciation effect than the US income effect, except Korea.

Exchange rate risk possesses significant effects on exports for all countries, negative or positive in periods of depreciation or appreciation.

\section{Asymmetric Effects of Exchange Rate Risk}

Table 5 reports results of the sum tests for the asymmetric effect of the exchange rate risk. The likelihood ratio (LR) statistic with a $\chi^{2}$ distribution and one degree of freedom tests the significance of the sum $\sum d_{1 i}, \sum\left(d_{1 i}+d_{2 i}\right)$, or $\sum d_{2 i}$, whether the total influence of exchange rate risk on exports equals zero for depreciations, for appreciations, or for the differences between the two sums. We define weal asymmetry if either $\sum d_{1 i}$ or $\sum\left(d_{1 i}+d_{2 i}\right)$ differ significantly from zero and strong asymmetry if $\sum d_{2 i}$ differs significantly from zero.

The sum of the coefficients of exchange rate risk in depreciation is significant for all countries except Singapore and Thailand. Five countries exhibit significant negative effects; one exhibits a significant positive effect. The magnitude of the sum ranges from 0.614 in Malaysia to -3.479 in Taiwan. The coefficient sum in appreciation is significant for Japan, Korea, Philippines,

\footnotetext{
${ }^{2}$ Fang and Miller (2004) report similar findings for Singapore, using a bilateral GARCH-M model with constant variance. Abeysinghe and Yeok (1998), using OLS, find that appreciation does not diminish Singapore's exports due to their high import content. Lower import prices reduce the cost of export production.
} 
Singapore, and Thailand. Three countries exhibit a significantly negative sum; two exhibit a significantly positive sum. The magnitude ranges from 0.494 for the Philippines to -3.671 for Singapore. Generally, the exchange rate risk affects exports for all countries. The effect proves negative for depreciations or appreciations in four countries -- Indonesia, Japan, Singapore, and Taiwan. It exhibits a mixed negative or positive effect for depreciations or appreciations for the other four countries -- Korea, Malaysia, the Philippines and Thailand. In sum, all eight countries exhibit weak asymmetry.

An asymmetric effect of exchange rate risk on exports exists, if either $\sum d_{1 i}$ or $\sum\left(d_{1 i}+d_{2 i}\right)$ (or both) significantly differs from zero and $\sum d_{2 i}$ also differs significantly from zero. Since the exchange rate risk exhibits significant effects on exports either in depreciation or appreciation (or both), the difference between the two coefficient sums, $\sum d_{2 i}$, determines the test. $\sum d_{2 i}$ significantly differs from zero for Japan, Korea, Malaysia, the Philippines, and Singapore. In sum, these five countries exhibit strong asymmetry. The difference between the two coefficient sums insignificantly differs from zero in Indonesia, Taiwan, and Thailand. Nonetheless, these three countries still exhibit weak asymmetry.

Exchange rate depreciation (appreciation) exhibits the expected positive (negative) effect on exports (i.e., $c_{i}$ coefficients) in each country, except for Malaysia and Singapore. The effect of exchange rate risk can complement or offset such exchange rate effects, depending on the country, whether the exchange rate depreciates (appreciates), and whether the exchange rate risk increases (decreases). Assuming that larger exchange rate adjustments associate with higher exchange rate risk, we can draw the following inferences from our estimates. If these Asian countries try to stimulate their exports by depreciating their currencies, those attempts to stimulate exports receive significant reinforcement from the exchange rate risk in Malaysia, but offsetting effects in Indonesia, Japan, Korea, the Philippines, and Taiwan. 
Previous empirical results on the effects of exchange rate risk without distinguishing asymmetric responses provide mixed results. As a comparison, we also estimate the symmetric-effect GARCH model in equations (1) to (9). Table 6 reports estimates. Diagnostic tests support the statistical appropriateness of the dynamic conditional correlation bivariate GARCH-M model. First, the positive effects of US manufacturing income of the two models produce a reasonable match. Second, significant positive depreciation effects exist for all eight countries in the symmetric effect model. Although they exhibit similar patterns in the two models, the effect proves insignificant in the asymmetric model for Malaysia and Singapore. That is, the symmetric model provides more evidence of positive depreciation effects than the asymmetric model. Third, the cumulative exchange rate risk effect in the symmetric model proves significantly negative for three countries -- Indonesia, Japan, and Taiwan - and not significant for the other five countries. These findings agree with the majority of prior studies, which conclude with either a negative exchange rate risk effect or no effect. In contrast, the asymmetric model identifies significant negative exchange rate risk effects for all countries, except Malaysia, for appreciations, depreciations, or both. Malaysia along with Korea and the Philippines exhibit significant positive effects for appreciations or depreciations. The asymmetric model that allows different responses during depreciations and appreciations provides more evidence of the effect of exchange rate risk on exports.

More recently, Klaassen (2004) finds no exchange rate risk effect on monthly bilateral US exports to other G7 countries, arguing that the exchange rate risk does not exhibit sufficient variability to uncover its effect on exports, and suggests studying the effect, using data on developing countries, for which much more volatile exchange rate risk may exist. The present paper uses data on monthly bilateral exports from eight Asian countries to the US -- seven developing and one developed. Applying the newly developed dynamic conditional correlation 
bivariate $\operatorname{GARCH}(1,1)-\mathrm{M}$ model and allowing asymmetric responses, we find significant exchange rate risk effects for all countries studied.

\section{Summary and Discussion}

This paper applies dynamic conditional correlation bivariate GARCH-M model to examine the asymmetric effects of exchange rate risk on exports, using monthly bilateral exports from eight Asian countries to the US over the period 1979 to 2003. The empirical results summarize as follows. For all the eight countries, foreign income affects exports positively and significantly with contemporaneous, one-month-lagged or two-month-lagged effects. Exchange rate depreciation exhibits the normal positive effect, but proves insignificant in two countries. Real exchange rate risk (volatility) produces significant effect on exports for all countries, negative or positive. Moreover, all countries also exhibit either weak or strong asymmetry with respect to exchange rate risk during appreciations and depreciations of the exchange rates. For Japan, Korea, Malaysia, the Philippines, and Singapore, the effects of exchange rate risk prove strongly asymmetric. The pattern of weak or strong asymmetry shows the following results. Indonesia, Japan, and Taiwan respond negatively to exchange rate risk during depreciations. Korea and the Philippines respond negatively to exchange rate risk during appreciations and positively in appreciations. Malaysia exhibits only a positive exchange rate risk effect during depreciations.

In sum, the conventional assumption of a symmetric effect of exchange rate risk at the aggregate level appears invalid. Given our asymmetric effects, then unfavorable effects of exchange rate risk on exports prove significant in five countries - Indonesia, Japan, Korea, the Philippines, and Taiwan - during depreciations, but in only three countries - Japan, Singapore, and Thailand - during appreciations. Unfavorable effects of exchange rate risk exist during depreciations and favorable effect during appreciations for Korea and the Philippines. The role of the exchange rate in determining export revenue may prove less predictable, given asymmetric 
effects. Consider the effect of depreciations in Korea and the Philippines. In Figure 2, their currencies depreciated substantially against the dollar in recent years, especially after the Asian crisis of 1997. Although both countries possess strong positive depreciation effects (the highest estimates among the eight countries in Table 3), the asymmetric effect generates a negative exchange rate risk effect, leading to an uncertain net effect of the depreciation on exports. This last statement assumes that the recent depreciation associates with higher exchange rate risk, which appears to be the case from Figure 2. The negative exchange rate risk effect could offset or even dominate the positive depreciation effect. For Malaysia, however, the asymmetric exchange rate risk effect reinforces the positive effect of depreciation.

Table 1: US share of total exports

\begin{tabular}{cc}
\hline Country & Share (\%)Ratio \\
\hline INDONESIA & 16.0 \\
JAPAN & 30.5 \\
KOREA & 26.5 \\
MALAYSIA & 17.6 \\
PHILIPPINES & 34.1 \\
SINGAPORE & 18.7 \\
TAIWAN & 32.8 \\
THAILAND & 18.7 \\
\hline
\end{tabular}

Note: The data are obtained from Direction of Trade of the IMF, exports to the US/total exports. 
Table 2: Preliminary statistics for exports and the exchange rate

\begin{tabular}{|c|c|c|c|c|c|c|c|c|}
\hline & \multicolumn{2}{|c|}{ INDONESIA } & \multicolumn{2}{|c|}{ JAPAN } & \multicolumn{2}{|c|}{ KOREA } & \multicolumn{2}{|c|}{ MALAYSIA } \\
\hline & $\Delta l x_{t}$ & $\Delta l q_{t}$ & $\Delta l x_{t}$ & $\Delta l q_{t}$ & $\Delta l x_{t}$ & $\Delta l q_{t}$ & $\Delta l x_{t}$ & $\Delta l q_{t}$ \\
\hline Sample size & 291 & 291 & 291 & 291 & 291 & 291 & 291 & 291 \\
\hline Mean & 0.486 & 0.336 & 0.218 & 0.020 & 0.542 & 0.123 & 0.617 & 0.254 \\
\hline SD & 23.561 & 6.257 & 5.263 & 2.792 & 10.886 & 2.785 & 9.815 & 2.085 \\
\hline Maximum & 112.428 & 56.678 & 15.506 & 6.801 & 41.158 & 34.325 & 36.894 & 14.890 \\
\hline Minimum & -120.641 & -26.884 & -18.577 & -10.068 & -42.280 & -8.509 & -32.974 & -15.417 \\
\hline \multirow[t]{2}{*}{ Skewness } & -0.166 & 3.026 & -0.035 & -0.609 & -0.186 & 6.678 & 0.049 & 0.348 \\
\hline & $(0.144)$ & $(0.144)$ & $(0.144)$ & $(0.144)$ & $(0.144)$ & $(0.144)$ & $(0.144)$ & $(0.144)$ \\
\hline \multirow[t]{2}{*}{ Kurtosis } & 8.475 & 32.407 & 3.787 & 3.757 & 5.013 & 82.118 & 4.118 & 26.085 \\
\hline & $(0.287)$ & $(0.287)$ & $(0.287)$ & $(0.287)$ & $(0.287)$ & $(0.287)$ & $(0.287)$ & $(0.287)$ \\
\hline J-B N & $364.801 *$ & $10929.82 *$ & $7.573 *$ & $24.945^{*}$ & $50.807^{*}$ & 78061.06* & $15.278^{*}$ & $6467.65^{*}$ \\
\hline$Q(3)$ & $70.030 *$ & $11.934^{*}$ & $52.199 *$ & $27.323^{*}$ & $70.169^{*}$ & $59.985^{*}$ & $68.233^{*}$ & $13.182 *$ \\
\hline$Q(6)$ & $77.207^{*}$ & $29.785^{*}$ & $66.728 *$ & $28.284^{*}$ & $90.065^{*}$ & $64.426^{*}$ & $70.957 *$ & $14.315^{*}$ \\
\hline$Q^{2}(3)$ & $62.163^{*}$ & $55.883^{*}$ & $14.311^{*}$ & $8.800^{*}$ & $44.415^{*}$ & $13.136^{*}$ & $19.944 *$ & $139.630 *$ \\
\hline$Q^{2}(6)$ & $62.257 *$ & $87.651^{*}$ & $16.013^{*}$ & $17.596^{*}$ & $47.158 *$ & $13.622 *$ & $26.883^{*}$ & $188.000 *$ \\
\hline $\mathrm{ADF}(\mathrm{m})$ & $-21.005 *(1)$ & $-14.494 *(0)$ & $-9.673 *(2)$ & $-12.641 *(0)$ & $-19.635 *(1)$ & $-12.047 *(1)$ & $-18.864 *(1)$ & $-13.875^{*}(0)$ \\
\hline \multirow[t]{3}{*}{$\rho_{x q}$} & \multicolumn{2}{|c|}{0.213} & \multicolumn{2}{|c|}{0.206} & \multicolumn{2}{|c|}{0.215} & \multicolumn{2}{|c|}{0.081} \\
\hline & \multicolumn{2}{|c|}{ PHILIPPINES } & \multicolumn{2}{|c|}{ SINGAPORE } & \multicolumn{2}{|c|}{ TAIWAN } & \multicolumn{2}{|c|}{ THAILAND } \\
\hline & $\Delta l x_{t}$ & $\Delta l q_{t}$ & $\Delta l x_{t}$ & $\Delta l q_{t}$ & $\Delta l x_{t}$ & $\Delta l q_{t}$ & $\Delta l x_{t}$ & $\Delta l q_{t}$ \\
\hline Sample size & 291 & 291 & 291 & 291 & 291 & 291 & 291 & 291 \\
\hline Mean & 0.622 & 0.186 & 0.487 & 0.095 & 0.283 & 0.053 & 1.031 & 0.196 \\
\hline SD & 9.528 & 2.702 & 12.145 & 1.411 & 8.956 & 1.560 & 11.542 & 2.609 \\
\hline Maximum & 35.601 & 21.006 & 55.490 & 6.380 & 37.592 & 9.020 & 49.175 & 16.295 \\
\hline Minimum & -38.113 & -8.687 & -54.574 & -4.995 & -25.208 & -6.546 & -43.237 & -15.911 \\
\hline \multirow[t]{2}{*}{ Skewness } & -0.050 & 2.577 & -0.218 & 0.069 & 0.407 & 0.109 & -0.144 & 1.872 \\
\hline & $(0.144)$ & $(0.144)$ & $(0.144)$ & $(0.144)$ & $(0.144)$ & $(0.144)$ & $(0.144)$ & $(0.144)$ \\
\hline \multirow[t]{2}{*}{ Kurtosis } & 5.418 & 20.495 & 6.618 & 4.950 & 4.645 & 7.954 & 6.404 & 24.106 \\
\hline & $(0.287)$ & $(0.287)$ & $(0.287)$ & $(0.287)$ & $(0.287)$ & $(0.287)$ & $(0.287)$ & $(0.287)$ \\
\hline J-B N & $71.019 *$ & $4033.18^{*}$ & $160.985^{*}$ & $46.330 *$ & $40.824 *$ & $298.168^{*}$ & $141.504 *$ & $5570.93 *$ \\
\hline$Q(3)$ & $64.406^{*}$ & $8.400 *$ & $100.780 *$ & $17.620^{*}$ & $89.918^{*}$ & $14.133^{*}$ & $38.784 *$ & $23.865^{*}$ \\
\hline$Q(6)$ & $66.996^{*}$ & 9.516 & $101.580^{*}$ & $20.500^{*}$ & $90.098^{*}$ & $22.365^{*}$ & $58.018 *$ & $28.645^{*}$ \\
\hline$Q^{2}(3)$ & $31.870^{*}$ & 6.203 & $59.289^{*}$ & $48.710^{*}$ & $36.352 *$ & 3.324 & $53.417^{*}$ & $129.850 *$ \\
\hline$Q^{2}(6)$ & $35.351^{*}$ & 8.823 & $59.721 *$ & $86.074^{*}$ & $39.742 *$ & 6.538 & $109.77 *$ & $187.150 *$ \\
\hline $\mathrm{ADF}(\mathrm{m})$ & $-18.787 *(1)$ & $-14.335 *(0)$ & $-19.291 *(1)$ & $-13.543 *(0)$ & $-20.683 *(1)$ & $-13.980 *(0)$ & $-14.982 *(1)$ & $-12.766^{*}(0)$ \\
\hline$\rho_{x q}$ & \multicolumn{2}{|c|}{0.259} & \multicolumn{2}{|c|}{0.046} & \multicolumn{2}{|c|}{0.018} & \multicolumn{2}{|c|}{0.110} \\
\hline
\end{tabular}

Note: $\quad$ SD represents standard deviation; J-B N denotes Jacque-Bera normality test; $Q(k)$ and $Q^{2}(k)$ are Ljung-Box statistics for the level and squared terms for autocorrelations up to k lags; and $\mathrm{ADF}(\mathrm{m})$ is the augmented Dickey-Fuller unit root test with lags $\mathrm{m}$ selected by the SIC criterion.

* denotes significance at the 5-percent level.

** denotes significance at the 10-percent level. 
Table 3: Estimates for dynamic conditional correlation bivariate GARCH-M model (1a)-(9)

\begin{tabular}{|c|c|c|c|c|c|c|c|c|c|c|c|c|c|c|c|c|}
\hline & \multicolumn{2}{|c|}{ INDONESIA } & \multicolumn{2}{|c|}{ JAPAN } & \multicolumn{2}{|c|}{ KOREA } & \multicolumn{2}{|c|}{ MALAYSIA } & \multicolumn{2}{|c|}{ PHILIPPINES } & \multicolumn{2}{|c|}{ SINGAPORE } & \multicolumn{2}{|c|}{ TAIWAN } & \multicolumn{2}{|c|}{ THAILAND } \\
\hline & Coefficient & $\begin{array}{c}\text { Standard } \\
\text { error }\end{array}$ & Coefficient & $\begin{array}{c}\text { Standard } \\
\text { error }\end{array}$ & Coefficient & $\begin{array}{c}\text { Standard } \\
\text { error }\end{array}$ & Coefficient & $\begin{array}{c}\text { Standard } \\
\text { error }\end{array}$ & Coefficient & $\begin{array}{c}\text { Standard } \\
\text { error }\end{array}$ & Coefficient & $\begin{array}{c}\text { Standard } \\
\text { error }\end{array}$ & Coefficient & $\begin{array}{l}\text { Standard } \\
\text { error }\end{array}$ & Coefficient & $\begin{array}{c}\text { Standard } \\
\text { error }\end{array}$ \\
\hline$a_{0}$ & $1.832 *$ & 0.413 & $4.901 *$ & 0.123 & $1.007^{* *}$ & 0.557 & 0.439 & 0.403 & 0.401 & 0.286 & $4.555^{*}$ & 0.277 & $4.622 *$ & 0.358 & $1.182 *$ & 0.316 \\
\hline$a_{1}$ & $-0.649^{*}$ & 0.048 & $-0.574^{*}$ & 0.044 & $-0.600^{*}$ & 0.050 & $-0.628^{*}$ & 0.048 & $-0.629 *$ & 0.046 & $-0.697^{*}$ & 0.049 & $-0.712 *$ & 0.047 & $-0.654 *$ & 0.051 \\
\hline$a_{2}$ & $-0.354^{*}$ & 0.046 & $-0.269^{*}$ & 0.038 & $-0.302^{*}$ & 0.046 & $-0.254^{*}$ & 0.050 & $-0.241^{*}$ & 0.044 & $-0.251^{*}$ & 0.048 & $-0.292^{*}$ & 0.044 & $-0.329 *$ & 0.045 \\
\hline$b_{0}$ & $2.988^{*}$ & 0.674 & $1.387^{*}$ & 0.303 & $1.749^{*}$ & 0.742 & & & $1.621^{*}$ & 0.484 & $2.651^{*}$ & 0.596 & $1.295^{*}$ & 0.579 & $2.075^{*}$ & 0.739 \\
\hline$b_{1}$ & & & & & & & $1.745^{*}$ & 0.600 & $1.401^{*}$ & 0.429 & & & $1.554^{*}$ & 0.562 & & \\
\hline$b_{2}$ & & & $0.984^{*}$ & 0.282 & & & & & & & & & & & $1.207^{*}$ & 0.572 \\
\hline$c_{0}$ & $0.362 *$ & 0.053 & & & $0.708^{*}$ & 0.128 & & & $1.229 *$ & 0.181 & 0.226 & 0.215 & & & $0.554^{*}$ & 0.086 \\
\hline$C_{1}$ & & & $0.304 *$ & 0.063 & $1.032 *$ & 0.115 & & & $0.738^{*}$ & 0.115 & & & $0.820^{*}$ & 0.228 & $0.540^{*}$ & 0.072 \\
\hline$C_{2}$ & $0.210^{*}$ & 0.074 & $0.286^{*}$ & 0.077 & $0.737^{*}$ & 0.090 & 0.288 & 0.205 & $0.215^{* *}$ & 0.123 & & & & & $0.286^{*}$ & 0.087 \\
\hline$d_{10}$ & & & & & $-1.461^{*}$ & 0.145 & $1.240^{*}$ & 0.184 & $-0.446^{* *}$ & 0.240 & & & & & & \\
\hline$d_{11}$ & & & $-1.410^{*}$ & 0.036 & $-1.723^{*}$ & 0.262 & & & $0.706^{*}$ & 0.156 & & & $-3.479 *$ & 0.233 & $0.199 *$ & 0.030 \\
\hline$d_{12}$ & $-0.376^{*}$ & 0.072 & & & $2.392 *$ & 0.216 & $-0.626^{*}$ & 0.184 & $-0.996 *$ & 0.243 & $-2.339^{*}$ & 0.153 & & & & \\
\hline$d_{20}$ & $0.579 *$ & 0.096 & $-0.627^{*}$ & 0.075 & & & & & $0.632 *$ & 0.250 & & & & & $0.372 *$ & 0.118 \\
\hline$d_{21}$ & $-0.400 *$ & 0.109 & $-0.334^{*}$ & 0.080 & & & $-0.783 *$ & 0.239 & $0.598 *$ & 0.202 & $-1.332^{*}$ & 0.075 & $0.758 *$ & 0.350 & $-0.813^{*}$ & 0.050 \\
\hline$d_{22}$ & & & & & $1.011^{*}$ & 0.187 & & & & & & & & & $-0.422 *$ & 0.092 \\
\hline$S_{0}$ & 0.069 & 0.057 & 0.187 & 0.185 & 0.033 & 0.070 & $0.113^{* *}$ & 0.063 & 0.005 & 0.095 & 0.043 & 0.071 & 0.087 & 0.091 & -0.042 & 0.059 \\
\hline$S_{1}$ & $0.207 *$ & 0.065 & $0.308^{*}$ & 0.060 & $0.351^{*}$ & 0.052 & $0.177^{*}$ & 0.067 & $0.357^{*}$ & 0.059 & $0.235^{*}$ & 0.054 & $0.212 *$ & 0.061 & $0.211^{*}$ & 0.061 \\
\hline$\gamma_{1}$ & $30.261 *$ & 1.508 & & & & & & & & & & & & & $6.072 *$ & 0.643 \\
\hline$\gamma_{2}$ & $16.552 *$ & 0.495 & & & & & & & & & & & & & $15.066^{*}$ & 0.329 \\
\hline$\alpha_{0}$ & $1.642 *$ & 0.609 & $13.189^{*}$ & 1.496 & $36.998^{*}$ & 4.438 & $5.713^{*}$ & 1.277 & $8.213^{*}$ & 3.289 & $7.257^{*}$ & 1.082 & $42.448^{*}$ & 5.102 & $1.464^{*}$ & 0.504 \\
\hline$\alpha_{1}$ & $0.079 *$ & 0.012 & $0.204^{*}$ & 0.094 & $0.404^{*}$ & 0.077 & $0.143^{*}$ & 0.028 & $0.249^{*}$ & 0.086 & $0.271^{*}$ & 0.013 & $0.177^{*}$ & 0.090 & $0.085^{*}$ & 0.008 \\
\hline$\alpha_{2}$ & $0.901 *$ & 0.010 & & & $0.303 *$ & 0.023 & $0.793 *$ & 0.021 & $0.721 *$ & 0.073 & $0.675^{*}$ & 0.028 & & & $0.887^{*}$ & 0.007 \\
\hline$\beta_{0}$ & $0.251^{*}$ & 0.043 & $6.112^{*}$ & 0.317 & $0.108^{*}$ & 0.020 & $0.796^{*}$ & 0.097 & $0.695^{*}$ & 0.178 & $0.268^{*}$ & 0.008 & $1.834 *$ & 0.182 & $0.078^{*}$ & 0.011 \\
\hline$\beta_{1}$ & $0.451^{*}$ & 0.074 & $0.191 *$ & 0.043 & $0.094^{*}$ & 0.017 & $0.333^{*}$ & 0.088 & $0.338^{*}$ & 0.104 & $0.086^{*}$ & 0.009 & $0.186^{*}$ & 0.060 & $0.087^{*}$ & 0.003 \\
\hline$\beta_{2}$ & $0.309^{*}$ & 0.047 & & & $0.781 *$ & 0.021 & & & $0.425^{*}$ & 0.070 & $0.766^{*}$ & 0.016 & & & $0.798^{*}$ & 0.013 \\
\hline$\lambda_{1}$ & $12.008 *$ & 4.216 & & & $0.713^{*}$ & 0.255 & $42.343^{*}$ & 20.030 & $9.095 * *$ & 4.961 & & & & & $12.431 *$ & 4.790 \\
\hline$\lambda_{2}$ & & & & & & & & & $16.388^{* *}$ & 9.253 & & & & & & \\
\hline$v$ & $5.951 *$ & 1.074 & $6.835^{*}$ & 1.729 & $4.051^{*}$ & 0.409 & $5.170^{*}$ & 0.831 & $3.018^{*}$ & 0.202 & $7.315^{*}$ & 1.814 & $4.822 *$ & 0.704 & $6.433 *$ & 1.047 \\
\hline$\theta_{1}$ & $0.135^{*}$ & 0.061 & $0.024^{*}$ & 0.004 & $0.111^{*}$ & 0.051 & $0.032 *$ & 0.001 & $0.200^{*}$ & 0.058 & $0.056^{* *}$ & 0.029 & $0.073 *$ & 0.026 & $0.029^{*}$ & 0.014 \\
\hline$\theta_{2}$ & $0.717^{*}$ & 0.131 & $0.670^{*}$ & 0.024 & $0.712 *$ & 0.008 & $0.930 *$ & 0.001 & $0.462 *$ & 0.116 & $0.695^{*}$ & 0.171 & $0.755^{*}$ & 0.198 & $0.891 *$ & 0.022 \\
\hline$\rho_{x q, t}$ & 0.1 & & & 201 & & 112 & 0.0 & 11 & 0.1 & & & 044 & 0.0 & 14 & & 064 \\
\hline$Q_{2}(6)$ & 35.1 & & 19.2 & & 30. & 017 & 28.9 & & 32.5 & & 11.3 & & 28.6 & & 31. & 584 \\
\hline$Q_{2}^{2}(6)$ & 12.0 & & 20.0 & & 16. & 656 & 9.5 & 93 & 29.2 & & 21.8 & & 22.3 & & 25. & 184 \\
\hline$L R(k)$ & 3.360 & $0(6)$ & 4.51 & $10(7)$ & 2.91 & $16(4)$ & 10.16 & $6(8)$ & 1.72 & $6(2)$ & 2.00 & $2(8)$ & 4.71 & 4(9) & 5.92 & $26(3)$ \\
\hline
\end{tabular}

Note: $\quad Q_{2}(6)$ and $Q_{2}^{2}(6)$ are the bivariate Ljung-Box statistics (Hosking,1980) of the standardized and squared standardized residuals for autocorrelations up to 6 lags. $L R(k)$ is the likelihood ratio statistic following a $\chi^{2}$ distribution with the degree of freedom $k$ (in the parentheses) that tests that the restricted simple model has the same explanatory power as the unrestricted general model when we eliminate the $k$ insignificant estimates.

* denotes significance at the 5-percent level.

** denotes significance at the 10-percent level. 
Table 4: Statistics for dynamic conditional correlations

\begin{tabular}{cccccccccc}
\hline & INDONESIA & JAPAN & KOREA & MALAYSIA & PHILIPPINES & SINGAPORE & TAIWAN & THAILAND \\
\hline Mean & 0.110 & 0.201 & 0.112 & 0.011 & 0.169 & 0.044 & 0.014 & 0.064 \\
Median & 0.106 & 0.202 & 0.134 & 0.021 & 0.183 & 0.053 & -0.001 & 0.063 \\
Maximum & 0.609 & 0.305 & 0.396 & 0.155 & 0.494 & 0.246 & 0.420 & 0.220 \\
Minimum & -0.413 & 0.094 & -0.453 & -0.155 & -0.392 & -0.185 & -0.270 & -0.104 \\
Std. Dev. & 0.197 & 0.029 & 0.127 & 0.065 & 0.118 & 0.066 & 0.116 & 0.052 \\
\hline
\end{tabular}

Table 5: Tests of asymmetric effect of exchange rate risk

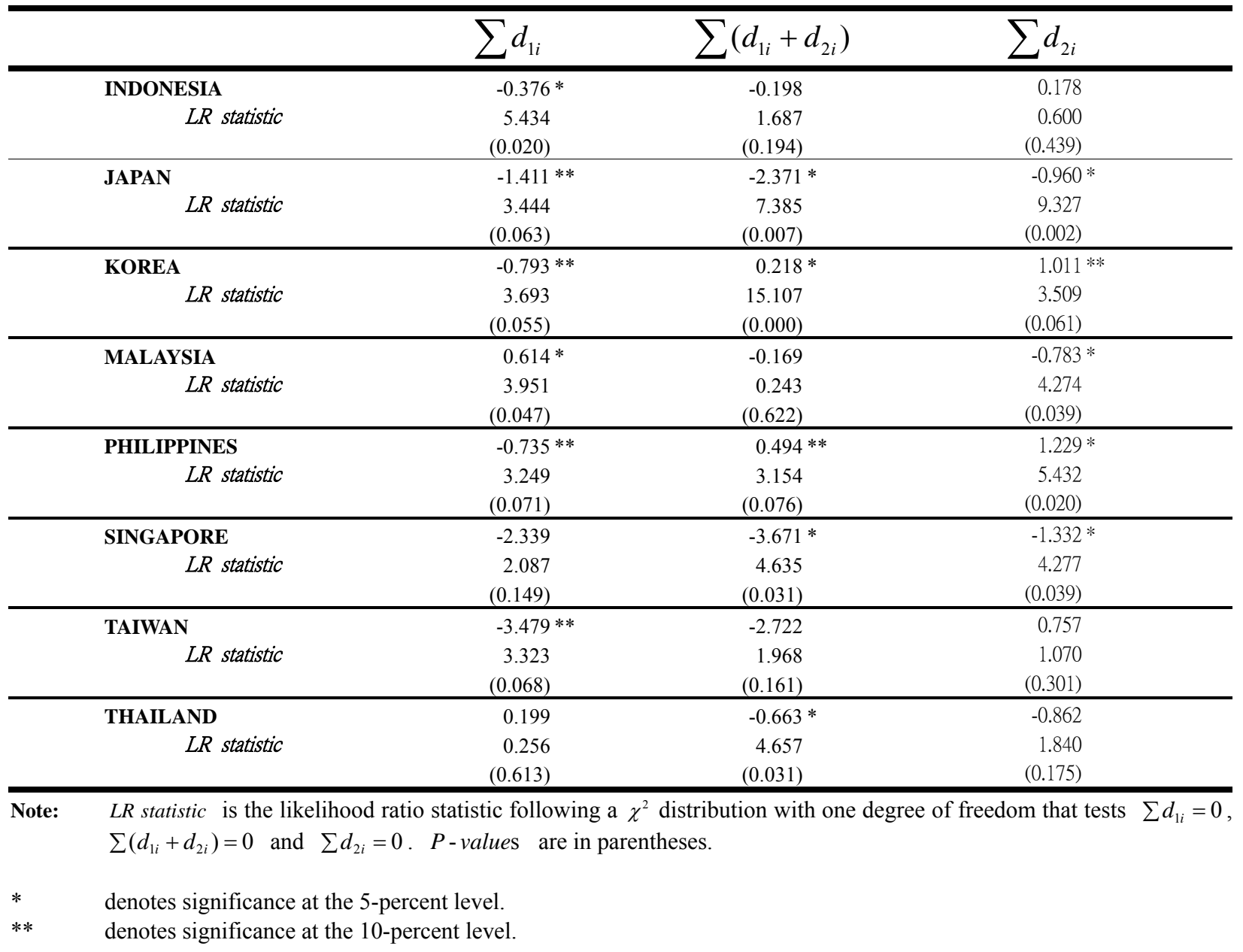


Table 6: Estimates for dynamic conditional correlation bivariate GARCH-M model (1)-(9)

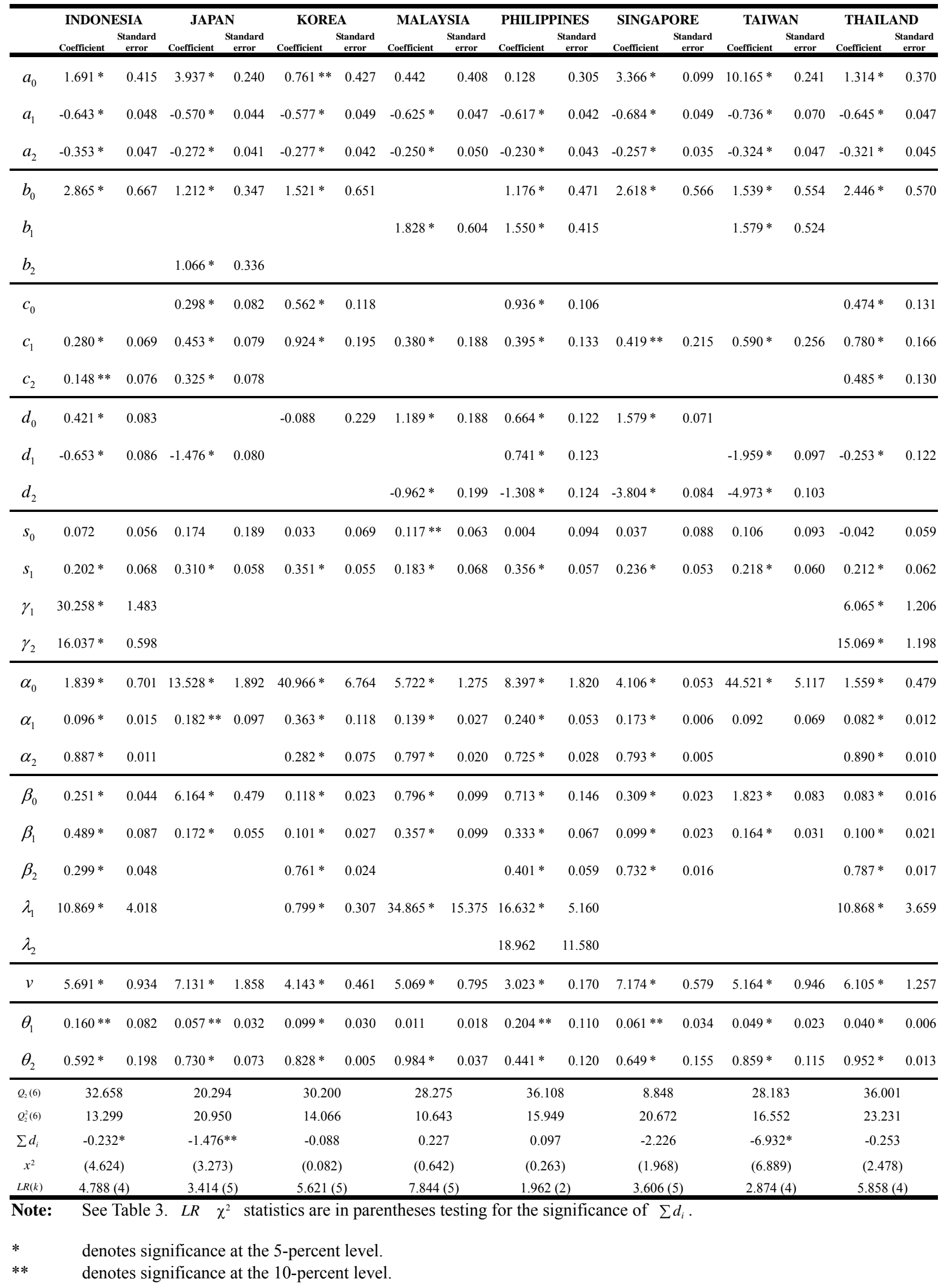



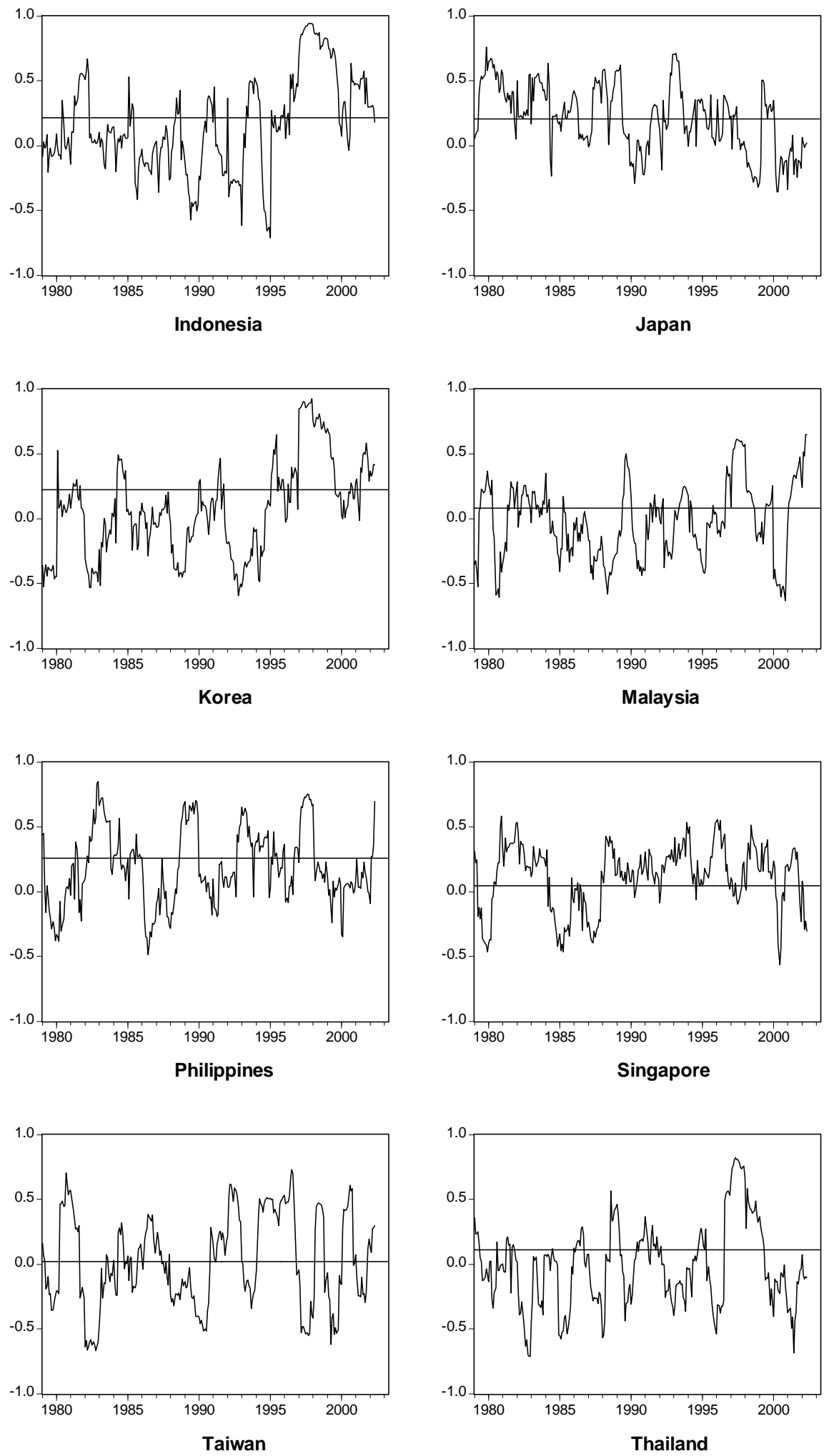

Figure 1. 12-period rolling correlations 

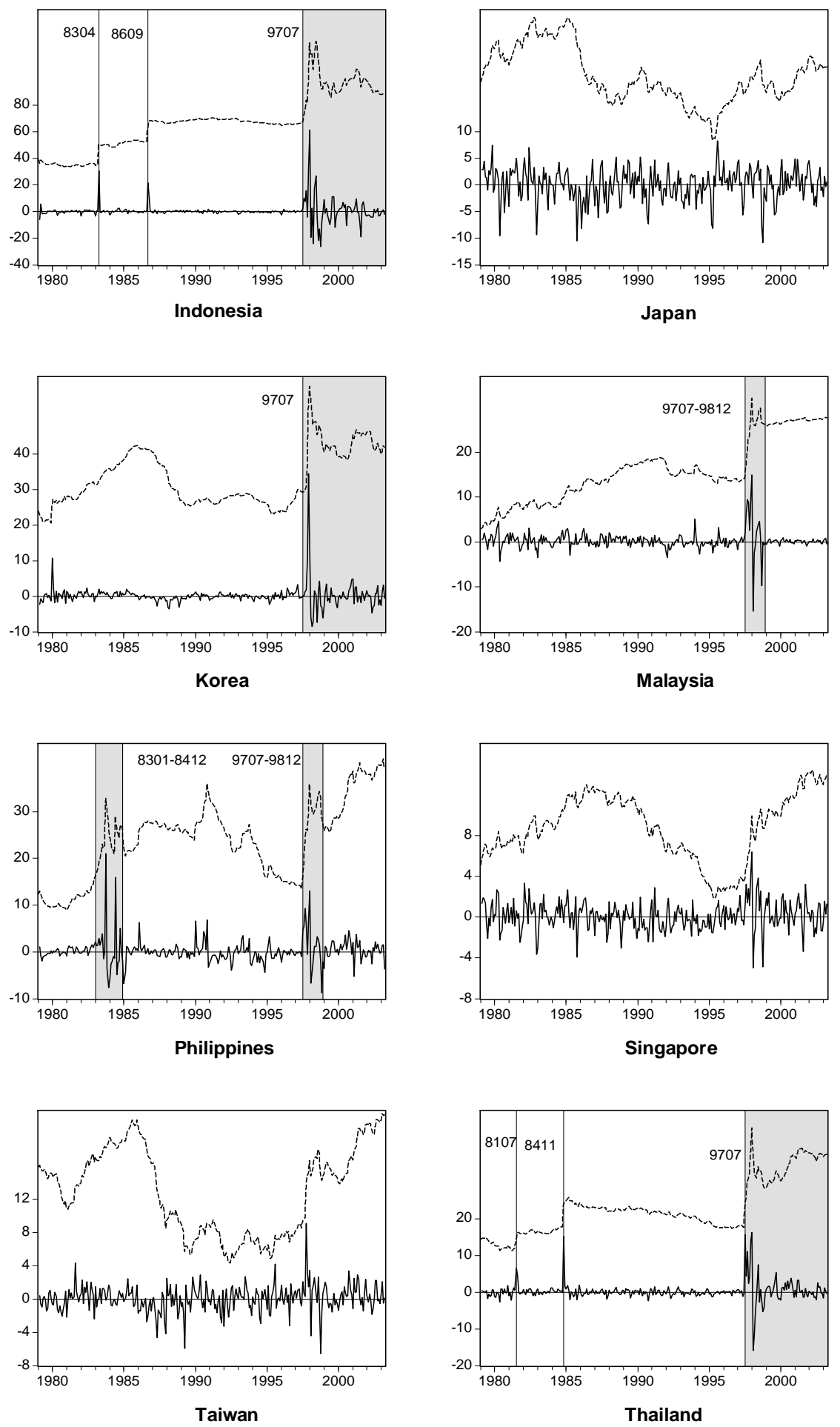

- Percentage Change of Real Exchange Rate ---- Real Exchange Rate

Figure 2. Structural changes for exchange rates 

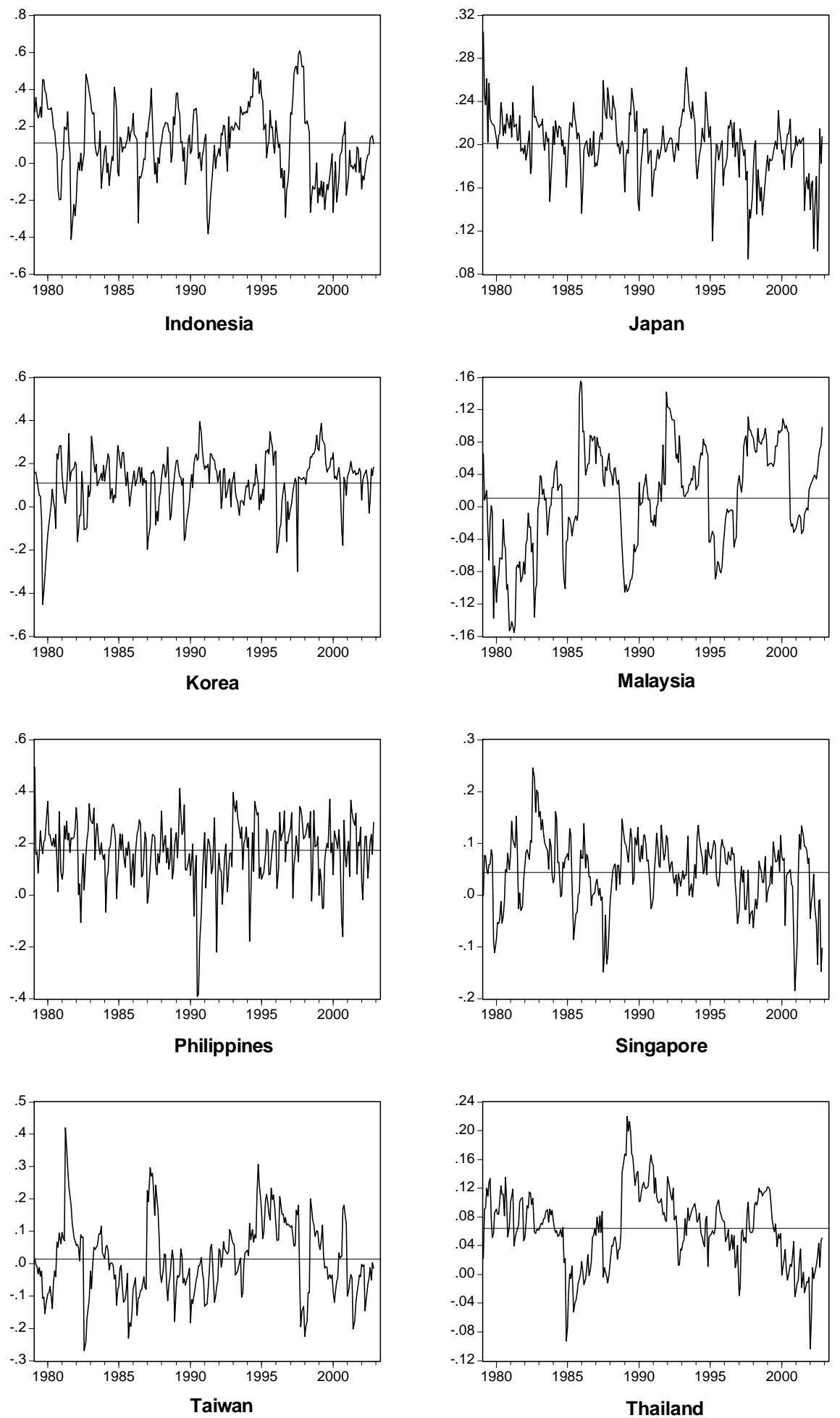

Figure 3. Dynamic conditional correlations 


\section{References}

Abeysinghe, T. and Yeok, T. L. (1998) "Exchange Rate Appreciation and Export Competitiveness. The Case of Singapore," Applied Economics 30, 51-55.

Arize, A. C. (1995) "The Effects of Exchange-Rate Volatility on U.S. Exports: An Empirical Investigation," Southern Economic Journal 62, 34-43.

Arize, A. C. (1996) "Real Exchange-Rate Volatility and Trade Flows: The Experience of Eight European Economies," International Review of Economics and Finance 5, 187-205.

Arize, A. C. (1997) "Foreign Trade and Exchange-Rate Risk in the G-7 Countries: Cointegration and Error-Correction Models," Review of financial Economics 6, 95-112.

Arize, A. C, Osang, T. and Slottje, D. J. (2000) "Exchange-Rate Volatility and Foreign Trade: Evidence From Thirteen LDC's," Journal of Business and Economic Statistics 18, 10-17.

Arize, A. C., Malindretos, J. and Kasibhatla, K. M. (2003) "Does Exchange-Rate Volatility Depress Export Flows: The Case of LDCs," International Advances in Economics Research 9, 7-19.

Asseery, A. and Peel, D. A. (1991) "The Effects of Exchange Rate Volatility on Exports: Some New Estimates,” Economics Letters 37, 173-177.

Bollerslev, T. (1986) “Generalized Autoregressive Conditional Heteroscedasticity," Journal of Econometrics 31, 307-327.

Bollerslev, T. (1990) "Modeling the Coherence in Short-run Nominal Exchange Rates: A Multivariate Generalized ARCH Approach," Review of Economics and Statistics 72,498-505.

Bollerslev, T., Chou, R. J. and Kroner K. F. (1992) “ARCH Modeling in Finance: A Review of the Theory and Empirical Evidence," Journal of Econometrics 52, 5-59.

Broll, U. and Eckwert, B. (1999) "Exchange Rate Volatility and International Trade," Southern Economic Journal 66, 178-185. 
Chowdhury, A. R. (1993) "Does Exchange Rate Volatility Depress Trade Flows? Evidence From Error-Correction Models," Review of Economics and Statistics 75, 700-706.

De Grauwe, P. (1988) "Exchange Rate Variability and The Slowdown in Growth of International Trade," IMF Staff Papers 35, 63-84.

Engle, R. F., Lilien, D. M. and Robins, R. P. (1987) “Estimating Time-Varying Risk Premia in the Term Structure: The ARCH-M Model," Econometrica 55, 391-407.

Engle, R. F. (2002) "Dynamic Conditional Correlation: A Simple Class of Multivariate Generalized Autoregressive Conditional Heteroskedasticity Models," Journal of Business and Economic Statistics 20, 339-350.

Ethier, W. (1973) "International Trade and the Forward Exchange Market," American Economic Review 63, 494-503.

Fang, WenShwo, and Miller, S. M. (2004) "Exchange Rate Depreciation and Exports: The Case of Singapore Revisited," manuscript, University of Nevada, Las Vegas.

Fang, WenShwo, and Thompson, H. (2004) "Exchange Rates Risk and Export Revenue in Taiwan," Pacific Economic Review 9, 117-129.

Frankel, J. A., Romer, D. and Cyrus, T. (1996) "Trade and Growth in East Asian Countries: Cause and Effect?" NBER Working papers 5732.

Hodrick, R. J. and Srivastava, S. (1984) "An Investigation of Risk and Return in Forward Foreign Exchange,” Journal of International Money and Finance 3, 5-29.

Hosking, J. R. M. (1980) "The Multivariate Portmanteau Statistic," Journal of the American Statistical Association 75, 602-608.

Kanas, A. (1997) "Is Economic Exposure Asymmetric between Long-run Depreciations and Appreciations? Testing Using Cointegration Analysis," Journal of Multinational Financial Management 7, 27-42.

Knetter, M. M. (1994) "Is Export Price Adjustment Asymmetric? Evaluating the Market Share and Marketing Bottlenecks Hypothesis,” Journal of International Money and Finance 13, 
$55-70$.

Klaassen, F. (2004) "Why is it so Difficult to Find an Effect of Exchange Rate Risk on Trade?" Journal of International Money and Finance 23, 817-839.

Kroner, K. F. and Lastrapes, W. D. (1993) "The Impact of Exchange Rate Volatility on International Trade: Reduced Form Estimates Using the GARCH in Mean Model," Journal of International Money and Finance 12, 298-318.

Krugman, P. (1987) "Pricing to Market When the Exchange Rate Changes," in S. W. Arndt and J. D. Richardson, eds., Real Financial Linkages among Open Economies, MIT Press, Cambridge, Mass., 49-70.

McKenzie, M. D. and Brooks, R. D. (1997) "The Impact of Exchange Rate Volatility on German-U.S. Trade Flow," Journal of International Financial Markets, Institutions and Money 7, 73-87.

Mahdavi, S. (2000) "Do German, Japanese, and U.S. Export Prices Asymmetrically Respond to Exchange Rate Changes? Evidence from Aggregate Data," Contemporary Economic Policy 18, 70-81.

Perron, P. (1989) "The Great Crash, the Oil Price Shock, and the Unit Root Hypothesis," Econometrica 57, 1361-1401.

Perron, P. (1997) "Further Evidence on Breaking Trend Functions in Macroeconomic Variables," Journal of Econometrics 80, 355-85.

Pozo, S. (1992) "Conditional Exchange-Rate Volatility and the Volume of International Trade: Evidence from the Early 1990s," Review of Economics and Statistics 74, 325-329.

Rose, A. (1990) "Exchange Rates and the Trade Balance: Some Evidence from Developing Countries," Economics Letters 34, 271-275.

Sercu, P. (1992) "Exchange Rate Risk, Exposure, and the Option to Trade," Journal of International Money and Finance 11, 579-593. 
Tsay, R. S. (2002) Analysis of Financial Time Series, New York: John Wiley \& Sons.

Tse, Y. K. and Tsui, K. C. (1997) "Conditional Volatility in Foreign Exchange Rates: Evidence from the Malaysia ringgit and Singapore Dollar," Pacific-Basin Financial Journal 5, 345-356.

Tse, Y. K. and Tsui, K. C. (2002) "A Multivariate Generalized Autoregressive Conditional Heteroscedasticity Model with Time-varying Correlations," Journal of Business and Economic Statistics 20, 351-362.

Weliwita A., Ekanayake, E. M. and Tsujii, H. (1999) "Real Exchange Rate Volatility and Sri Lanka's Exports to the Developed Countries, 1978-96," Journal of Economic Development 24, 147-165. 